noids, recently obtained by a zealous collector, $\mathrm{Mr}$. Wood, from the mountain limestone near Richmond in Yorkshire, and which, from the perfection of the specimens obtained, leaves little to desire respecting its illustration. This genus, Woodocrinus, is allied to Cyathocrinus and Forbesiocrinus, differing from the latter in possessing subradial pieces, and from the former in having five of these plates instead of four. Another peculiarity is found in the stem, which, unlike most of the Crinoids, is very slender at the commencement and gradually increases in diameter with its length.

Prof. de Koninck is at present engaged on a general treatise of the Crinoidea, and has recently visited this country for the purpose of obtaining specimens and examining the collections in order to perfect his work; therefore any assistance connected with this subject would not be rendered in vain; for although two valuable works are in progress, those of Mr. Austin and M. d'Orbigny, there is still room for further researches on these singular lilyform creatures, which swarmed so abundantly in the earlier seas, and whose almost entire absence in the present ocean is probably compensated for, or at least represented by, the higher members of the same family of Echinoderms.

\title{
A Lecture on the Geological History of Newbury, Berks.
} By T. Rupert Jones, F.G.S.

This pamphlet, containing the substance of a lecture delivered before the members of a scientific institute, has however more than a local interest. In treating of the physical history of a limited district, the author has brought forward certain geological truths in a clear and intelligible manner. Popular lectures are not always satisfactory, partly from the ad captandum style, sometimes from a discursive array of undigested facts, and frequently from the lecturer speaking at and not to the audience.

The value of elementary instruction depends upon the correctness of the facts stated, and the clearness and methodical manner with which they are enunciated. In this respect Mr. Jones has been successful, by arranging the leading principles of geological science in a concise and common-sense manner. Geology is treated as a history, the records of which are to be sought for beneath the surface, in the constitution of the soils and subsoils of the district, in the beds of earth and stone, which compose the frame-work of hill and valley, and constitute, as it were, the many-leaved stony volume of the earth's primæval history. Cuvier long ago remarked, that the geologist was an antiquary of a new order. Just as the antiquary finds materials for history in the many buildings of towns and cities, whether perfect or in ruins, which have been erected for ecclesiastical, military or civil purposes, at different periods, in distinct styles, of various materials, and often rich with sculpture and inscriptions,so the geologist examines the many different rocks and soils of which 
the crust of the earth consists, notes the relative position of the several layers, studies their minerals, and compares their fossils.

In the deeper valleys around Newbury, the different members of the cretaceous formation crop out; and these are covered nearer the town by some of the members of the middle and lower tertiary series, which in their turn are overlaid by deposits of gravel, the adjacent valleys of the Kennett and Lambourne being partially occupied by peat-accumulations. As the different deposits here exhibited are but continuous portions of strata spread over more extensive areas, any remarks concerning the origin of local phænomena necessitate an inquiry into the successive changes which have obtained over larger regions of the earth's surface.

It is thus that local geology, when well explained, embraces larger views, embodies general principles, and points to their practical bearings. In this spirit the lecture is conceived. By examining the nature of the deposits, it is shown how these have been accumulated by the action of seas and rivers during a long period of time, under various conditions of climate, and with many changes in the relative position of land and sea. The order of the succession of these changes, and the description of their results, together with notices of the animals and plants that tenanted the lands and waters during this long period, are also treated of in this lecture.

Nor are the higher inducements to the study of natural science overlooked. There are a large class, even at present, to whom the nature and tendencies of geological science are a sealed book, and whose personal respect for its teachings, if it has dawned, has certainly not passed the miocene period. With some notions that the ground beneath us yields certain treasures, they have but little knowledge that it exhibits an order and arrangement consistent with the dictates of Infinite Wisdom. These persons, well-meaning though they may be, belong to a class not entirely extinct, who regard any allusion to the Volume of Nature as a book replete with lessons of divine truth, with feelings somewhat approaching to horror, forgetting that there is no true piety in depreciating the evidences to be derived from the study of the works of Nature.

The Appendix contains tables of the geological formations; diagrams illustrative of the geological structure of parts of Hampshire and Berkshire; detailed sections of the strata at some of the localities near Newbury which yield fossils, as well as an account of the peat-beds of the Kennet Valley, and also notices and illustrations of some of the characteristic fossils of the formations; so that this little treatise forms not only a useful guide to the physical structure of the district, but is also explanatory of the characters of the tertiary deposits in the western area of the London basin, while it may be equally consulted with advantage by the general reader, for the concise manner with which the leading points are enunciated. 


\section{$2 \mathrm{BHL}$ Biodiversity Heritage Library}

Jones, T. Rupert. 1856. "A lecture on the geological history of Newbury, Berks." The Annals and magazine of natural history; zoology, botany, and geology 17, 60-61. https://doi.org/10.1080/00222935608697469.

View This Item Online: https://www.biodiversitylibrary.org/item/19391

DOI: https://doi.org/10.1080/00222935608697469

Permalink: https://www.biodiversitylibrary.org/partpdf/11292

\section{Holding Institution}

Natural History Museum Library, London

\section{Sponsored by}

Natural History Museum Library, London

\section{Copyright \& Reuse}

Copyright Status: Public domain. The BHL considers that this work is no longer under copyright protection.

This document was created from content at the Biodiversity Heritage Library, the world's largest open access digital library for biodiversity literature and archives. Visit BHL at https://www.biodiversitylibrary.org. 